\title{
On Desert Sand Seas
}

\author{
by Nicholas Lancaster
}

Desert sand seas constitute an important part of the modern and ancient global environment. Their rock equi valents contain important oil and gas deposits and are unrivalled aquifers. The fluctuation of deserts has caused the decline and fall of ancient civilizations and in modern times tragedy in the Sahel. Yet little has been done to study deserts in a systematic way, and their Miocene to Recent history remains to be determined. This article reviews current research on hot, lowland deserts, especially in southern Africa, with an emphasis on palaeoenvironmental and palaeoclimatic reconstructions.

\section{Introduction}

Desert sand seas, or ergs, are important but poorly understood depositional systems, which occur throughout much of geological time. Today they cover more than $32,000 \mathrm{~km}^{2}$ and contain over $85 \%$ of the global inventory of aeolian sand. Many sand sea deposits also include minor but significant amounts of interdune lacustrine and extra-dune fluvial, lacustrine or marine deposits, which provide important evidence for reconstructing the history of the sand body.

Major areas of sand sea accumulation occur in the Old World deserts of the Sahara, Arabia, central Asia, Australia and southern Africa (Fig. 1), where dunes cover up to one-third of the area classified as arid. Since many of these aeolian deposits make up a significant percentage of the Quaternary sediments, the history of their accumulation can also reveal much about the Quaternary history of these regions. There is also evidence, in the form of dune systems now stabilized or fixed by vegetation, that many sub-tropical sand seas were much more extensive in glacial periods (Sarnthein, 1978). Such systems can provide valuable information on palaeowinds and circulation patterns.

In the geological record, sandstones considered to be largely aeolian in origin have been identified from the Precambrian to the Tertiary. They are particularly common in formations of Permian to Jurassic age, when extensive sand seas occurred on most continents (Wlader and Yardley, 1985). The majority of aeolian sandstones apparently accumulated in low-latitude desert regions as sand bodies comparable in

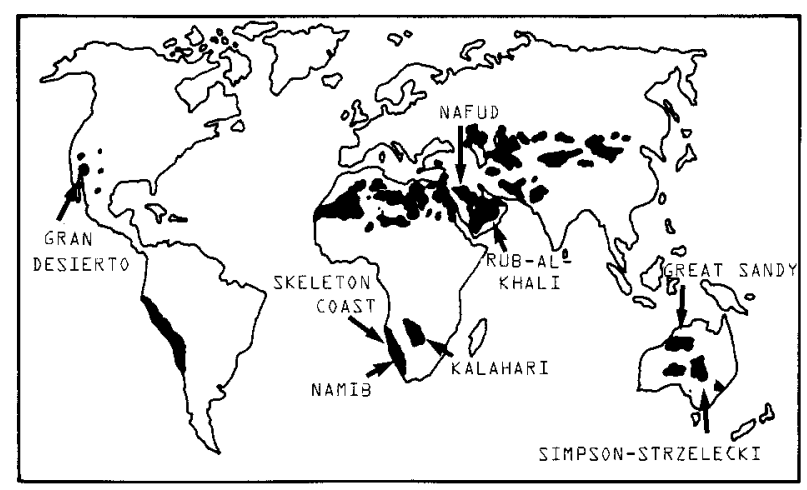

Figure 1: Distribution of major modern active sand seas. Note large concentration in the old world deserts. extent and depositional setting with modern sand seas. Thus the best way to understand the origins and depositional environments of ancient aeolian sandstones is to study modern dunes and their deposits, as advocated by Glennie (1970), Hunter (1977) and McKee (1979), though some allowance must be made for the late Mesozoic evolution of true desert angiosperm vegetation.

\section{Accumulation of Sand Seas}

Satellite images of desert regions, together with studies of regional wind regimes, have shown that sand seas are dynamic sedimentary bodies that form part of regional-scale transport systems (Wilson, 1971; Fryberger and Ahlbrandt, 1979; Mainguet, 1983; Lancaster, 1985). Sand is moved by the wind over long distances from coastal or alluvial source zones and is deposited wherever transport rates decrease. These may be reduced by topographic obstacles across sand transport paths, or more commonly, by regional climatic changes that lead to a decrease in wind velocity, an increase in the directional variability of the wind regime, or both.

Convergence in the lee of topographic obstacles (Mainguet, ibid), or in areas of low relief (Wilson, 1971), also has the same effect. Many ergs, particularly in the Sahara, are crossed by sand transport paths: the same winds that move material to a sand sea can also remove it, leading to a migration down-wind over time (Wilson, 1971; Mainguet, 1983). In the Namib Sand Sea of southwestern Africa (Fig. 1), for example, sand transport rates decrease inland and northward away from source areas close to the Orange River mouth and on the coast (Lancaster, 1985).

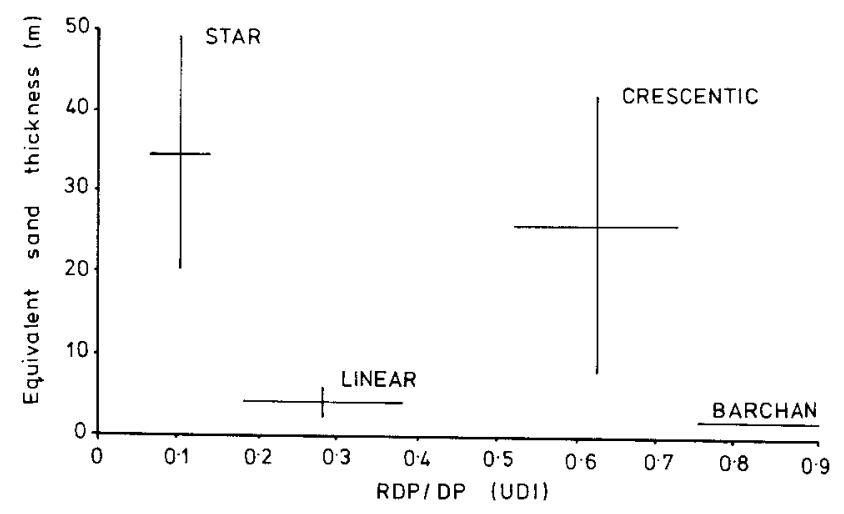

Figure 2: Occurrence of dunes of different types in global sample by Fryberger (1979) and their relationship to wind regimes of different directional variability. The UDI is the ratio between potential sand transport from the resultant direction (RD) and total potential sand transport (DP). From Wasson and Hyde (1983a).

The occurrence of dunes of different types in a sand sea, and the spatial variation in their size and spacing, may be regarded as the surface expression of the factors that control accumulation. Studies of the occurrence of major dune types (crescentic, linear or star) show that each is largely controlled by the directional variability of the wind 


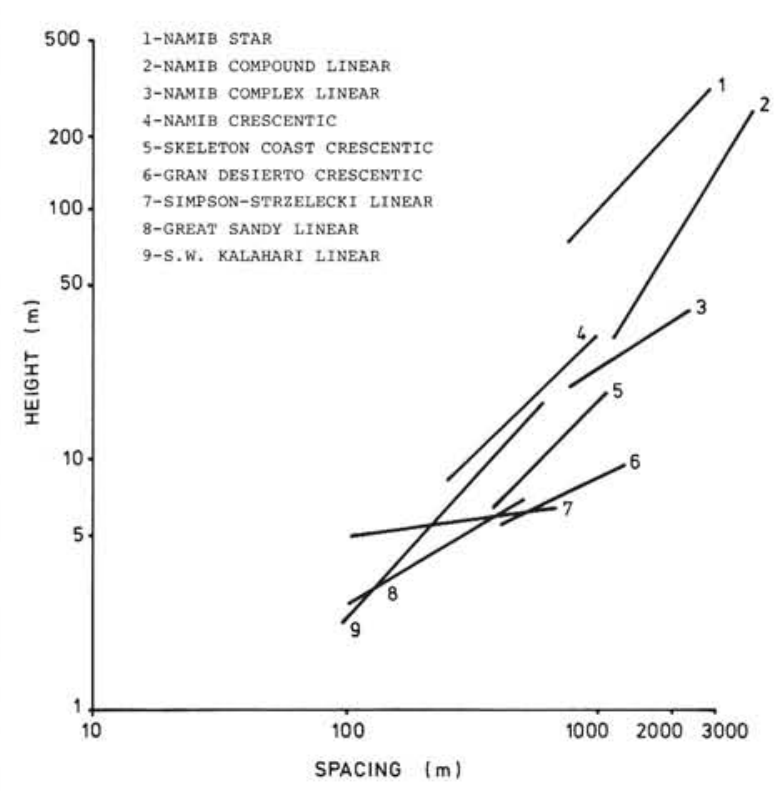

Figure 3: Relationship between dune height and spacing in different sand seas.

regime, expressed as the ratio between the resultant sand transport vector and the total potential vector (Fig. 2), with grain size, sand supply and vegetation cover playing a subordinate role (Fryberger, in McKee, 1979; Lancaster, in Brookfield and Ahlbrandt, 1983; Wasson and Hyde, 1983a). Figure 2 also illustrates the fact that different dune types contain varying amounts of sand, as expressed by their equivalent thickness. This is the depth of the layer that would be obtained if the sand of the dunes were spread evenly over the area between the dunes.

In the Namib Sand Sea the distribution of different kinds of dunes can be related mainly to regional changes in the directional variability of the wind regime (Lancaster, ibid.). Barchans and crescentic dunes occur in unidirectional wind regimes near the coast; linear dunes dominate over much of the sand sea, where bi-directional winds occur; and star dunes are associated with multi-directional wind regimes along the eastern margin of the sand sea. As in many ergs, upwind areas here are characterized by low dunes and sand sheets, which may represent deposits left behind by the migration of the sand sea (Kocurek and Nielson, 1986; Porter, 1986). Central areas of the sand sea are characterized by large compound and complex dunes.

Aerial photographs and satellite images of desert sand seas show that most dune patterns are very regular. There are close correlations between height, width and spacing (Breed and Grow, in McKee, 1979; Lancaster, in Brookfield and Ahlbrandt, 1983; Wasson and Hyde, 1983a, b). In many sand seas, height and spacing vary in a systematic way, with

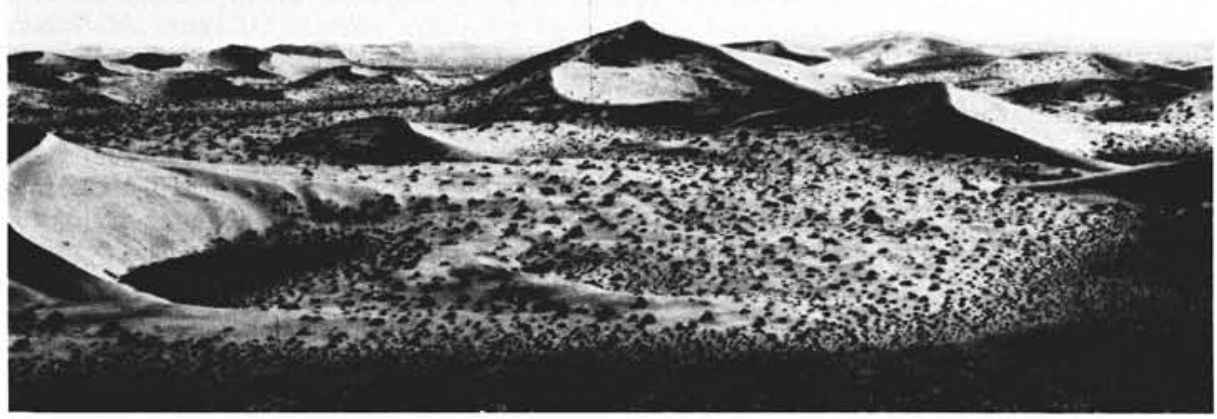

large dunes in central areas and progressively smaller ones towards the margins. The form of the relationship between height and spacing varies with type and location (Fig. 3), which suggests that dunes of different types develop in different ways. Complex and star dunes exhibit a tendency for vertical growth, indicating an abundant sand supply and a wind regime that promotes deposition on the dune, rather than its migration or extension. Alternatively, a given amount of sand can be formed into a few widely spaced dunes or many small closely spaced dunes, as in the Simpson Desert. However, the development of compound linear dunes in the Namib Sand Sea, linear dunes in the Great Sandy Desert and crescentic shape in the Gran Desierto appears to be limited by sand supply (Lancaster, in press).

In Namibia, data from studies of dune morphology can be combined with information on winds and transport rates to develop a model of sand sea formation in which material is moved inland from source areas to accumulate in large complex linear and star dunes in the center of the erg (Lancaster, ibid.). Data from linear and star dunes in the Namib Sand Sea show that their cross sectional area increases logarithmically with dune height. Areas of large complex dunes (Fig. 5), even though widely spaced, represent a greater accumulation of sand than do smaller, more closely spaced, simple and compound dunes. Information on dune size and equivalent thickness can be used to map the pattern of accumulation in a sand sea (Fig. 4).

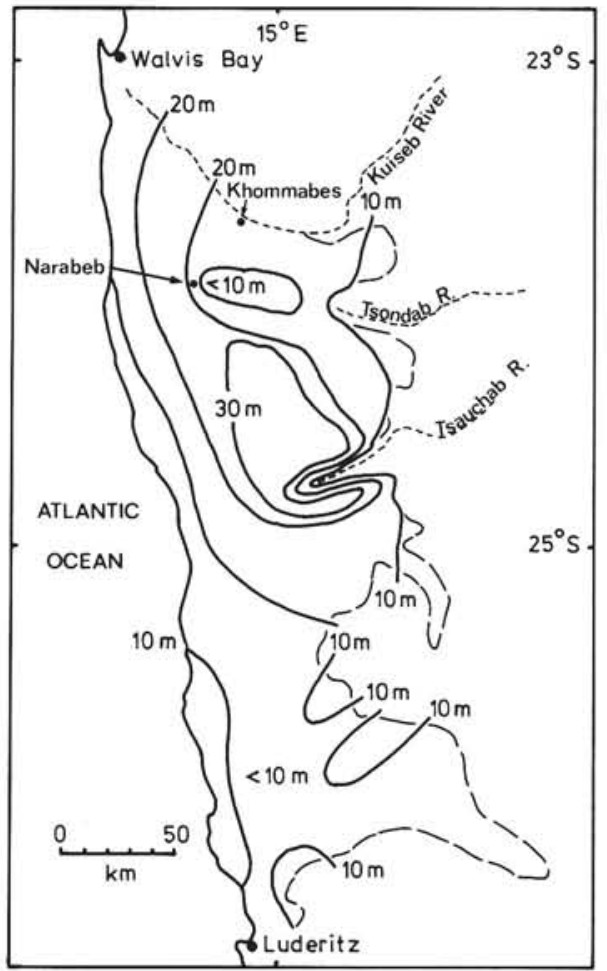

Figure 4: The pattern of aeolian deposition in the Namib Sand Sea, as represented by the spatial variation of the thickness equivalent to the amount of sand contained within the dunes. Long dashed line indicates margin of sand sea. Short dashed lines indicate ephemeral streams.

Figure 5: $80-120 \mathrm{~m}$ high star dunes in the Gran Desierto, Mexico. 


\section{The Palaeoenvironmental Record of Sand Seas}

Evidence from the world's major deserts, summarized by Street (1981), indicates that arid conditions developed from the end of the Miocene or Early Pliocene onwards (3-7 Ma). Most sand seas probably accumulated during this period, with their development strongly influenced by Quaternary climatic changes. In hyper-arid regions, such as the Namib, these changes have been of relatively low amplitude and duration about an arid to hyper-arid mean. However, in semi-arid areas such as Australia and the Kalahari, Quaternary climatic changes have been of much greater amplitude and duration.

Sand seas provide palaeoenvironmental information from three main sources: dune systems (especially those fixed by vegetation), interdune deposits, and penetration of outside fluvial deposits into the margins of the erg. The quality of palaeoclimatic data provided here is frequently much better than that obtained from adjacent rocky desert regions, for dune areas tend to accentuate the effects of both dry and wet phases (Rognon, 1982).

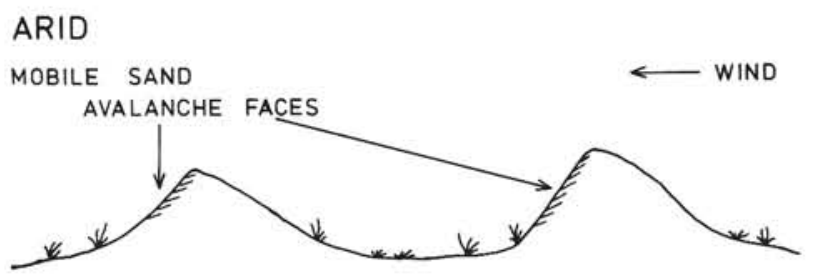

VEGETATION ON DUNE PLINTHS ONLY

$$
\begin{aligned}
& \text { SUB-ARID TO SEMI-ARID } \\
& \text { DUNE CRESTS MOBILE } \\
& \text { SMALL AVALANCHE FACES }
\end{aligned}
$$

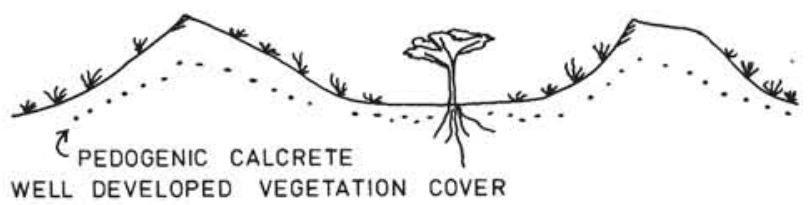

SEMI - ARID

DUNES STABILISED BY VEGETATION

MARSH AND LACUSTRINE DEPOSITION

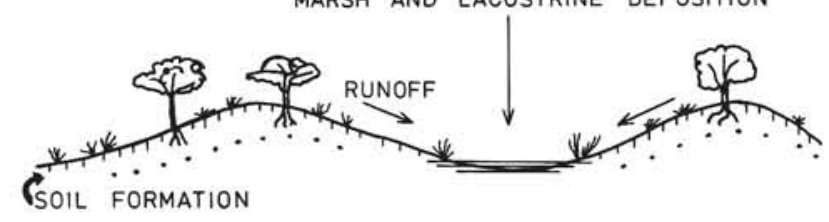

Figure 6: Schematic illustration of the effects of climatic change on sand seas. After Rognon, 1982.

In periods of increased rainfall, the high infiltration capacity and porosity of dune sands favours the growth and persistence of vegetation, which may lead to the formation of soils and partial or complete stabilization of the dunes (Fig. 6). If the periods of increased rainfall are of sufficient magnitude and duration, then water tables will rise, resulting in the accumulation of pond and marsh deposits in interdune areas. In periods of intense rainfall, runoff may erode dunes (Talbot, 1985). In contrast, periods of a ridity will give rise to a very unfavourable biotic environment within the erg, with low water tables and active sand movement preventing the growth of vegetation.

\section{Fixed Dune Systems}

Extensive systems of dunes, mostly fixed by vegetation (Fig. 7), have been recognized from the margins of modern active sand seas in the Sahel (Grove and Warren, 1968, Talbot 1984), southern Africa (Lancaster, 1981), India (Goudie et al., 1973) and Australia (Bowler and Wasson, in Vogel, 1984). Comparison of the precipitation limits of active and fixed dunes can provide an indication of the magnitude of changes in the position of climatic belts, but it is now clear that such comparisons are over-simplified. The importance of interactions between wind velocity and vegetation cover (and hence rainfall) on sand mobility are now being increasingly recognized in studies in Australia (Ash and Wasson, 1983), the Sahel (Talbot, 1984) and southern Africa (Lancaster, 1987).

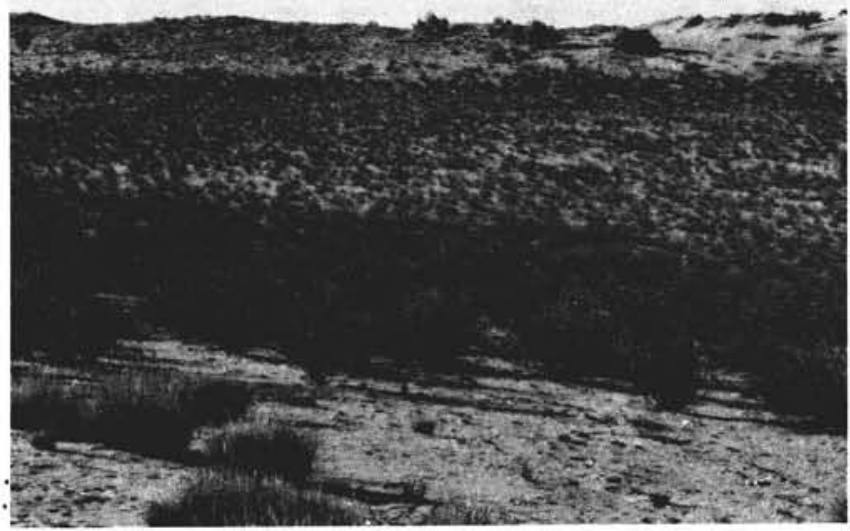

Figure 7: Linear dunes stabilized by savanna vegetation in the southwestern Kalahari sand sea. Dunes are 8-10 $\mathrm{m}$ high, spaced 400-500 m apart and aligned $N W-S E$.

The mobility of desert dunes is directly proportional to the power of the wind to move sand, but inversely proportional to their vegetation cover (Ash and Wasson, 1983). In turn, vegetation cover is a function of the ratio between annual rainfall $(\mathrm{P})$ and potential evapo-transpiration (PE). An index of the sand-moving power of the wind is the percentage of the time the wind is blowing above the threshold velocity (W) for sand transport $(4.5 . \mathrm{m} / \mathrm{second})$. The ratio of these two terms gives a mobility index: $M=W /(P / P E)$.

In southern Africa there is a gradient in sand mobility, as defined by this relationship, from the northern and eastern parts of the southwestern Kalahari to the active Namib Sand Sea (Fig. 8), which accurately parallels observations of the amounts of sand movement on dunes in the region (Lancaster, 1987). Critical values for $M$, based on the author's field observations, are similar to those of Talbot (1984) for the Sahel, and indicate that for $M$ values exceeding 200, dunes are fully active; between 100 and 200, dune plinths and interdunes are stabilized; between 50 and 100 , only dune crests are active; and less than 50, dunes are completely stabilized. It is clear from Figure 3 that significant increases in wind velocity or changes in the moisture balance occurred during periods when the dunes in the southwestern Kalahari were formed or remobilized.

The palaeoclimatic record for the southwestern Kalahari suggests that the dunes were active in the period 19,000$16,000 \mathrm{yBP}$, coeval with the last Glacial Maximum in high 
latitudes (Deacon and Lancaster, in press). During this period in southern Africa, mean annual temperatures were some $5^{\circ} \mathrm{C}$ colder than at present (Heaton et al., 1986), and Newell and his colleagues (1981) indicate that wind velocities at the latitude of the southwestern Kalahari would have been $117 \%$ of present values. An increase in wind velocity of this magnitude would have been sufficient to increase substantially the movement of sand, giving rise to an increase in $W$ from the present mean value of $17 \%$ to $37 \%$. Although PE would have been reduced as a result of lower temperatures, the increased windiness in the region would have been sufficient to reactivate dunes over most of the southern and western parts of the sand sea. However, to reactivate dunes in the northern and eastern parts of the southwestern Kalahari, changes in the moisture balance, involving a reduction in mean annual rainfall of 30-40\%, would have also been necessary (Fig. 8).

For the Sahel, Talbot (1984) concluded that, despite increased Late Pleistocene wind velocities, dune formation and reactivation in the period $25,000 / 20,000$ to $13,000 \mathrm{yBP}$ would have required a reduction in rainfall to $25-50 \%$ of present values. Ash and Wasson (1983) suggested that an increase in wind velocity of $20-30 \%$ in the Simpson desert would result in the mobilization of linear dunes. For the Late Pleistocene dune building phase $(20-13,000 \mathrm{yBP})$, Wasson (in Vogel, 1984) argued that increased windiness would have raised $\mathrm{PE}$ and enhanced aridity, even without any rainfall decrease. These variations in the palaeoclimates inferred for dune formation probably reflect regional differences in the limiting climatic factor for dune activity. More sophisticated modelling of the conditions for dune formation is required, especially for areas such as the southwestern U.S.A. where some of the climatic variables may be constrained by palaeobotanical evidence for temperatures and precipitation (e.g. Davis, 1987).

Comparisons between the modern pattern of sand-moving winds and dune alignments may provide important information on palaeocirculation patterns. In the Kalahari region of southern Africa, Lancaster (1981) recognized three systems of fixed dunes, each corresponding to a different palaeowind pattern. These systems suggest that Pleistocene and Holocene periods of aridity and dune formation in southern Africa were associated with, and probably caused by, increased persistence and strength of anticyclonic circulations, which prevented moisture-bearing winds from reaching the interior of the sub-continent.

\section{Interdune Deposits}

The extent and significance of interdune deposits in modern and ancient aeolian sedimentary environments is being increasingly recognized (Ahlbrandt and Fryberger, 1981; Kocurek, 1986). However, relatively little is known about the occurrence and characteristics of interdune deposits in modern sand seas. In the Namib Sand Sea, some 508 of all depositional surfaces consist of interdune areas. Wost of these are either gently undulating sand sheets deposited by wind ripple migration or exposures of the sub-dune surface. However, outcrops of calcareous mudstones and sandy limestones of Late Quaternary age are present in some interdunes (Fig. 9) in the northern part of the area (Lancaster and Teller, in press). As with similar deposits in the Sahara and Saudi Arabia (Rognon, 1987; Whitney et al., 1983), they have an importance that far exceeds their small extent. Interdune deposits can provide data on the chronology of sand accumulation through radiometric dating of carbonates and molluscs and studies of associated archaeological materials. They are also an important source of palaeoclimatic data for desert regions (Petit-Maire, 1986).

In the Namib Sand Sea, the carbonate-rich interdune lacustrine deposits are indicative of increased moisture availability in this normally arid to hyper-arid region. Diatom and molluscan faunas indicate that the water bodies were fresh to brackish in composition. Modern analogues suggest several possible depositional environments. Shallow seasonal or ephemeral lakes may have formed in interdune areas as a result of increased regional or local precipitation. Long-continued periods of increased rainfall may have raised local ground water levels to such that seepage from shallow aquifers occurred.

In some areas, such as at Khommabes on the northern margin of the Namib (Fig. 4), lakes may have formed adjacent to ephemeral water courses in response to high groundwater levels in those river valleys (Teller and Lancaster, 1986a). At other localities, for example at Narabeb, lakes developed at the former end points of ephemeral rivers, which at one time were able to penetrate much farther west into the Sand Sea than they do now (Teller and Lancaster, 1986b). This implies one or both of the following: rainfall and runoff in the headwaters of the rivers in the highlands east of the Sand Sea were at times greater, and linear dune patterns were sufficiently open to permit water to flow as much as $40 \mathrm{~km}$ west of the present terminal playas of these rivers.

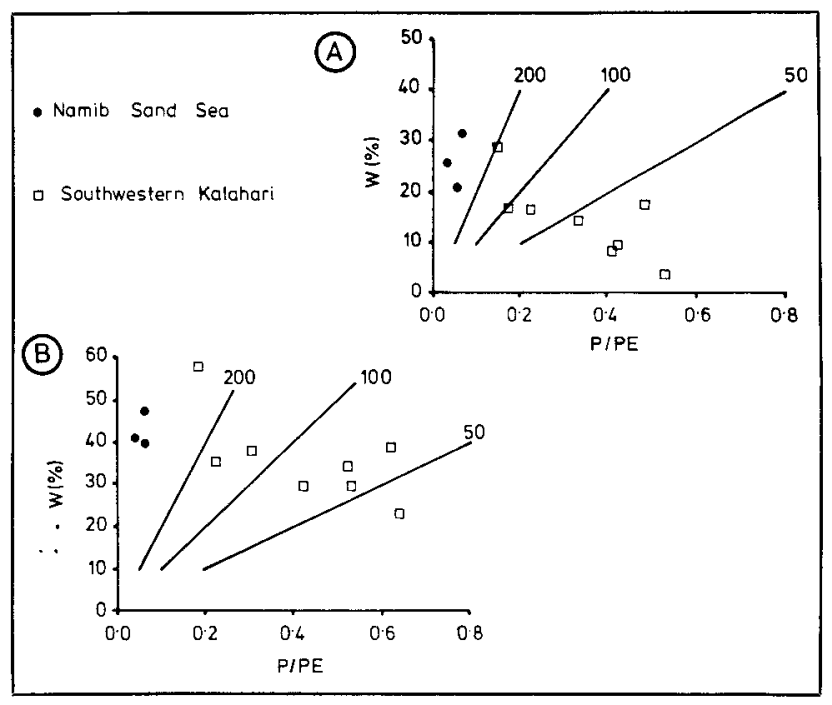

Figure 8: Relationship between the percentage of time the wind is above threshold velocity for sand transport (W) and effective precipitation ( $P / P E$ ) for arid areas in southern Africa today (A) and at 18,000 yBP (B).

In the Namib, radiocarbon dates on many of the interdune lacustrine carbonates and molluses cluster between 20,000 and 32,000 yBP (Vogel and Visser, 1981; Teller and Lancaster, 1986b; Lancaster and Teller, in press). Evidence from elsewhere in the arid zone of southern Africa (Deacon et al., in Vogel, 1984) indicates that rainfall throughout this climatic zone was probably significantly higher during the period when these lacustrine beds were deposited. In northern Saharan sand seas, increased flooding of the Wadi Saoura and lakes in the Chott Djerid basin, also indicate increased moisture availability between 40,000 and 20,000 yBP (Rognon, 1987).

Similarly wet conditions occurred in the southern Sahara during the same interval and again in the Holocene between 9000 and $7000 \mathrm{yBP}$, when lacustrine conditions were very extensive (Petit-Maire, 1986; Rognon and Williams, 1977; Talbot, 1984). In Saudi Arabia, interdune lacustrine deposits from the Nafud and Rub-al-Khali sand seas indicate moist conditions between 32,000 and $24,000 \mathrm{yBP}$ and again between 8,500 and $5,000 \mathrm{yBP}$ (Whitney et al., 1983). It appears, therefore, that the period leading up to the last Glacial Maximum was a time of substantially increased moisture in many subtropical sand seas. 
Interpreting the Rock Record of Ancient Aeolian Sandstones

Modern desert sand seas are dynamic sedimentary bodies that accumulate in response to regional variations in sand transport rates. Relatively little is, however, known of the vertical sequence of deposits in most modern sand seas, and there are only general indications as to how they have accumulated.

Information on spatial variations in dune type and the amount of sand accumulation derived from studies of dune morphology can be used to develop new facies models for wind-borne deposits, as Porter (1986) has shown. The basal deposits of many aeolian sandstones are those of the leading edge of the sand sea. They are characterized by the intertonguing of aeolian deposits with those of the adjacent depositional environment (e.g. marine, fluvial) as the sand sea expands or migrates downwind. The deposits of the central parts of the erg are represented by thick sequences of compound cross-strata deposited by the slow migration of large compound and complex dunes, with occasional lenses of fine-grained or carbonate interdune deposits. The uppermost deposits in the sequence are those of the upwind or trailing edge of the sand sea and may consist of thin, of ten coarse-grained aeolian deposits, interstratified with those of the upwind depositional environment. Such models can be tested against the rock record and improved by studies of modern sand seas.

Examination of the record of climatic changes preserved in the deposits of modern sand seas suggests that periods of dune formation may have been interrupted by long periods of stability, which may also include deposition of interdune lacustrine deposits. For example, within the past 40,000 years, active dune formation in many sand seas appears to have been restricted to the interval between about 20,000 and $12,000 \mathrm{yBP}$, and to the late Holocene (as much as one third of this period). This observation has considerable significance for interpretations of the rock record of aeolian sandstones, some of which like the Permian Rotliegendes sandstone of northwestern Europe also accumulated at a time of high-latitude glacial conditions (Glennie, in Brookfield and Ahlbrandt, 1983).

The recent recognition of extensive regional-scale superbounding surfaces (discontinuities) between sets of crossstrata in a number of ancient aeolian sandstones in the western U.S.A. (e.g. Peterson and Pipiringos, 1979; Blakey and Middleton, in Brookfield and Ahlbrandt, 1983; Driese and Dott, 1984; Loope, 1985) implies that these thick aeolian sandstones accumulated not as a single long-lived sand body, but as a series of genetically independent sand seas of relatively short duration separated by long hiatuses when the dunes were partly or completely planed off (Loope, ibid; Talbot, 1985; Kocurek, 1986). This may have been the result of changes in climate, sea level or tectonic setting, or the migration of the sand sea as a body (Kocurek, ibid). It is probable that the sedimentary record of modern desert sand seas reflects a similar pattern of episodic development, with Quaternary climatic changes being a major influence on the rate and nature of sand sea accumulation.

\section{Conclusions}

Studies of the dynamies and history of modern aeolian sand seas can help us to better understand the Quaternary history of desert regions. They can also assist in the interpretation of features of ancient aeolian sandstones, such as the formation of super-bounding surfaces and their significance in basin evolution.

Detailed investigations of modern sand seas are not easy to accomplish, for on a scale similar to those represented by the Jurassic sandstones of the western U.S.A., these areas cover hundreds of square kilometres in exceedingly inhospitable desert terrain. Basic information on wind regimes here is often unavailable, making it difficult to correlate dune types with wind regimes, and to understand dune and sand sea dynamics.

Establishing the Quaternary history of many sand seas is also hampered by the poor preservation of palaeosols and lacustrine deposits, and by the absence of clear stratigraphic relationships between dune and interdune deposits. Dating of arid episodes is most often achieved by bracketing them between periods of wetter conditions for which radiocarbon determinations are available. Thermoluminescence techniques offer great promise for dating dunes, but are still in an early stage in their development.

Advances in our understanding of the development of desert sand seas are most likely to come as a result of combining regional-scale studies using remote sensing techniques with detailed studies of selected areas. We need to focus our attention on the dynamics and processes involved in sand sea formation and accumulation, and to develop techniques that will enable us to document them reliably.

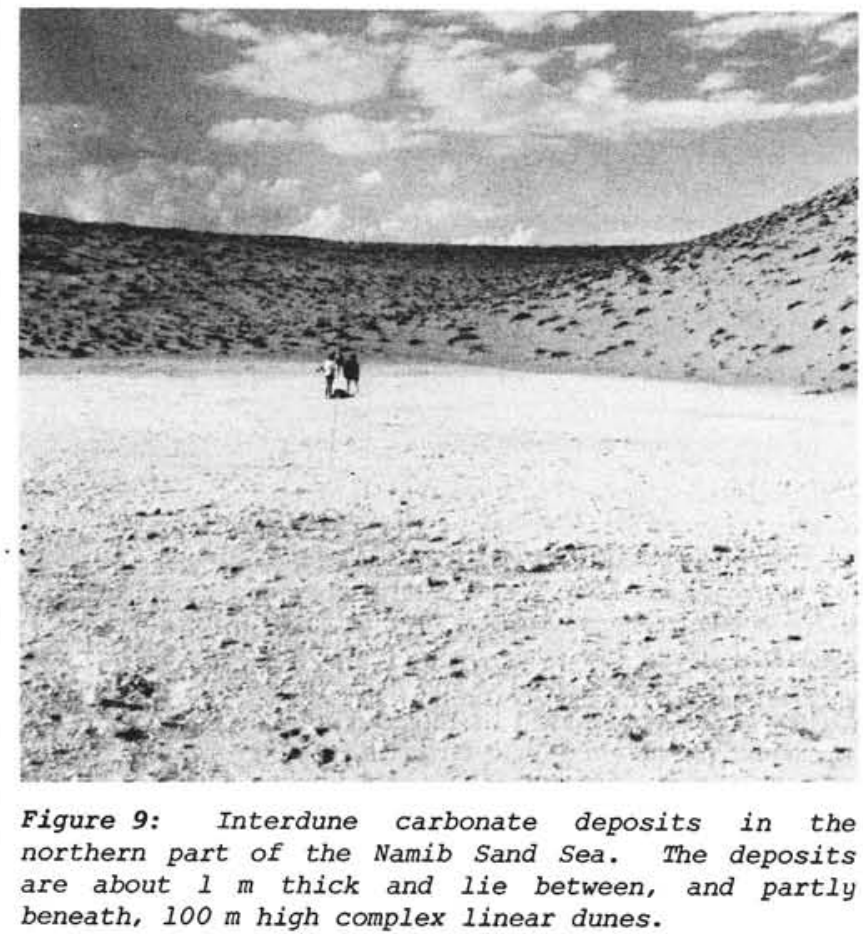

Acknowledgement: Michael Bookfield made several helpful comments which are incorporated in this article.

Dr. N. Lancaster is based in the Department of Geology at Arizona State University (Tempe, Arizona 85287-1404, U.S.A.). He has worked on dune morphology and dynamics and on palaeoenvironments in the Namib and Kalahari deserts of southern Africa. He is currently studying the dynamics and formation of star dunes in the Gran Desierto sand sea of northern Mexico.

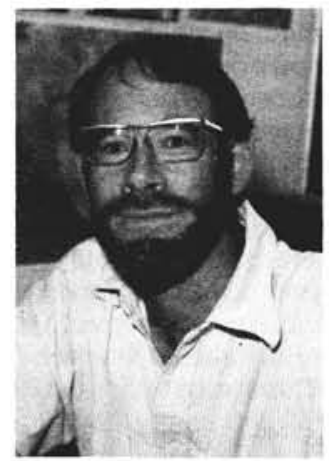


References

Ahlbrandt, T.S. and Fryberger, S.G., 1981. Sedimentary features and significance of interdune deposits. In: Ethridge,
F.G. and Flores, R.M. (eds.), Recent and Ancient F.G. and Flores, R.M. (eds.), Recent and Ancient Non-marine Depositional Environments: Models for
Exploration. Society of Economic Paleontologists and Exploration. Society of Economic Paleontolo
Nineralogists Special Publication 31, p. 293-324.

Ash, J.E. and Wasson, R.J. 1983. Vegetation and sand mobility in the Australian desert dunefield. Dunes, In: Jennings, J. and Hagedorn, If. (eds.), Dunes, Continental and Coastal. Zeitschrift fur Geomorphologie, Supplement band v. 45 , p. $7-25$.

Brookfield, M.E. and Ahlbrandt, T.S. (eds.), 1983. Eolian Sediments and Processes. Developments in Sedimentology, Sediments and Processes. Deve
v. 38 . Elsevier, Amsterdam.

Davis, O.K., 1987. Recent developments in the study of arid lands. Episodes, v. 10, no. 1, p. 41-42.

Deacon, J., Lancaster, N. and Scott, L., 1984. Evidence for Late Quaternary climatic change in southern Africa: Summary of the Proceedings of the SASQUA Quaternary Workshop held in Johannesburg, September 1983. In: Vogel, J.C. (ed.), Late Cainozoic Palaeoclimates of the Southern Hernisphere. Balkema, Rotterdam, p. 391-404.

Deacon, J.D. and Lancaster, $N$., in press. Late Quaternary Palaeoenvironments of Southern Africa. Clarendon Press, Oxford.

Driese, S.G. and Dott, R.H., Jr., 1984. Model for sandstone-carbonate "cyclothems" based on Upper ivember of Whorgan Formation (Middle Pennsylvanian of northern Utah and Colorado. American Association
ogists Bulletin, v. 68, no. 5, p. 574-597.

Fryberger, S.G. and Ahlbrandt, T.S., 1979. Mechanisms for the formation of eolian sand seas. Zeitschrift fur Geomorphologie, v. 23 , no. 4 , p. 440-460.

Glennie, K.W., 1970. Desert Sedimentary Environments. Developments in Sedimentology, v. 14 . Elsevier, Developments in Sedimentology, v. $14 . \quad$ Elsevier,
Ansterdam, 222p. Goudie, A.s., Alkchin, B. and Hegde, K.T.M., 1973. The former extensions of the Great Indian Sand Desert. Geographical Journal, v. 139, part 2, p. 243-257.

Grove, A.T. and Warren, A., 1968. Quaternary landforms and climate on the south side of the Sahara. Geographical Journal, v. 134, part 2, p. 194-208.

Heaton, T.H.E., Talma, A.S. and Vogel, J.C., 1986. Dissolved gas palaeotemperatures and 180 variations derived from groundwater near Uitenhage, South Africa. Quaternary Research, v. 25, no. 1, p. 79-88.

Hunter, R.E., 1977. Basic types of stratification in small eolian dunes. Sedimentology, v. 24, no. 3, p. 361-387.
Kocurek, G., 1981. Significance of interdune deposits and bounding surfaces in a eolian dune sands. Sedimentology, v. 28 , no. 6, p. $753-780$.

Kocurek, G., 1986. Origins of low-angle stratification in aeolian deposits. In: Nickling, W.G. (ed.), Aeolian Geomorphology. Proceedings of the 17 th Annual Binghamton Geomorphology Symposium. Allen and Unwin, London, p. 176193.

Kocurek, G. and Nielson, J., 1986. Conditions favourable for the formation of warm-climate eolian sand sheets. Sedimentology, v. 33, по. 6, p. 795-816.

Lancaster, N., 1981. Palaeoenvironmental implications of fixed dune systems in southern Africa. Palaeogeography, Palaeoclimatology, Palaeoecology, v. 33, no. 4, p. 327-346. Lancaster, N., 1985. Winds and sand movements in the Namib sand sea. Earth

Lancaster, N., 1987. Formation and reactivation of dunes in Lancaster, N., 1987. Formation and reactivation of dunes in Palaeoecology of Africa, v. 18, Balkema, Rotterdam, palaeoecology

Lancaster, N., in press. The development of large aeolian bedforms. Sedimentary Geology, v. 55 .

Lancaster, N., Greeley, R. and Christensen, P.R., 1987. Surface Processes and lanaforms, $v, 12$, Do, $3,0.277-288$.

Lancaster, N. and Teller, J.T., in press. Interdune deposits of the Namib Sand Sea. Sedimentary Geology, v. 55 .

Loope, D.B., 1985. Episodic deposition and preservation of eolian sands: a late Paleozoic example

MeKee, E.D. (ed.), 1979. A study of global sand seas. U.S. Geological Survey Professional Paper 1052, p. 429.

Mader, D. and Yardley, M.J., 1985. Migration, modification and merging in aechan systems and the signifieance of the depositional mechanisms in Permian and Triassic dune sands of Europe and North America. Sedimentary Geology, v. 43, no. $1-4$, p. $85-218$.

Mainguet, M., 1983. Tentative mega-morphological study of the Sahara. In: Gardner, R. and Scoging, H. (eds.), MegaJeomorphology. Clarendon Press, Oxford, p. 113-133.

Newell, R.E., Gould-Steward, S. and Chung, J.C., 1981. A possible interpretation of paleoclimatic reconstructions for Palgeocology of Africa, 13,13 , Balkema, Rottertam, $10{ }^{\circ}$ 19.
Palaeoecology of Africa, v. 13, Balkema, Rotterdam, p. 1Peterson, F. and Pipiringos, G.N., 1979. Stratigraphic relations of the Navajo sandstone to Middle Jurassic Forma tions, southern Utah and northern Arizona. U.S. Geologica Survey Professional Paper 1035B, p. 1-43.
Petit-Maire, N, 1986. Palaeoclimates in the Sahara of Mali. pisodes, v. 9, no. 1, p. 7-16.

Porter, M.L., 1986. Sedimentary record of erg migration. Geology, v. 14, no. 6, p. 497-500.

Rognon, P., 1982. Pluvial and arid phases in the Sahara: the role of non climatic factors. P

Rognon, P., 1987. Late Quaternary climatic reeonstruction Maghreb (North Africa). Paleogeography, Paleoclimatology, Paleoecology, v. 58, no. 2, p. 11-34.

Rognon, P. and williams, M.A.J., 1977. Late Quaternary climatic changes in Australia and North Africa: a preliminary interpretation. Palaeogeography, Paleoclimatology, Paleoecology, v. 21, no. 4, p. 285-328.

Sarnthein, M., 1978. Sand deserts during glacial maximum and climatic optimum. Nature, v. 272 , no. 5648, p. 43-46.

Street, F.A., 198k. Tropical paleoenvironments. Progress in Physical Geography, v. 5, no. 2, p. 157-185.

Talbot, M.R., 1984. Late Pleistocene rainfall and dune building in the Sahel. Palaeoecology of Africa, v. 16, Balkema, Rotterdam, p. 203-214.

Talbot, 2H.R., 1985. Major bounding surfaces in aeolian sandstones: a climatic model. Sedimentology, v. 32, no. 2, p. $257-266$

Teller, J.T. and Lancaster, N., 1986a. History of sediments at Khommabes, central Namib desert. Madoqua, v. 14, no. 4 , p. $409-420$.

Teller, J.T. and Lancaster, N., 1986b. Lacustine sediments at Narabeb in the central Namib desert, Namibia. Palaeogeography, Paleoelimatology, Paleoecology, v. 56 , no. $3-4$,

Vogel, J.C. (ed.), 1984. Late Cainozoic Palaeoclimates of the Southern Hemisphere. Balkema, Rotterdarn, 520p.

Vogel, J.C. and Visser, E., 1981. Pretoria radiacarbon dates II. Radiocarbon, v. 23 , no. 1, p. 43-80.

Wasson, R.J. and Hyde, R., 1983a. Factors determining dune type. Nature, v. 304, no. 5924, p. 337-339.

Wasson, R.J. and Hyde, R., 1983b. A test of granulometric control of desert dune geometry. Earth Surface Processes and Landforms, v. 8, no. 4, p. 301-312.

Whitney, J.W., Faulkender, D.J. and Rubin, M., 1983. The Environmental History and Present Condition of Saudi Arabia's northern sand seas. U.S. Geological Survey Open file report 83-0749. Minist ry of Petroleum and Mineral Resources Deputy Minister for Mineral Resources, Jeddah Saudi Arabia, $42 \mathrm{p}$

Wilson, 1.G., 1971. Desert sandflow basins and a model for the development of ergs. Geographical Journal, v. 137, part 2, p. 180-199.

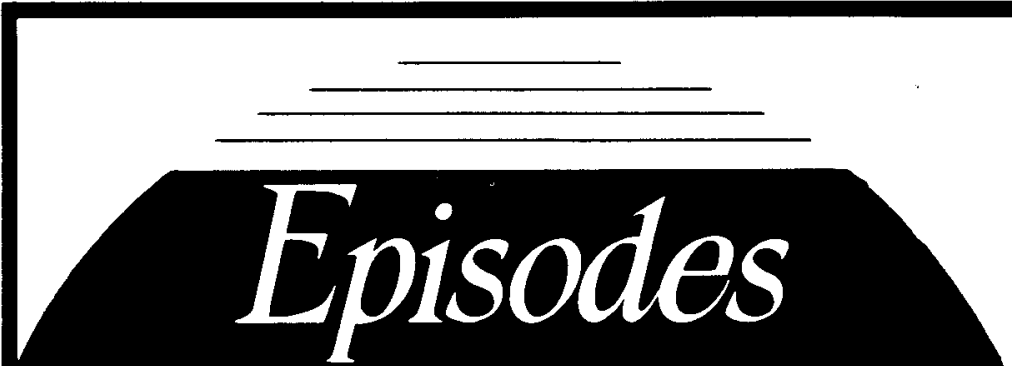

EARTH SCIENTISTS must contend with rapidly advancing knowledge and an ever-growing information base. They must also keep pace with a bewildering diversity of organizations and a wide array of conferences, seminars and workshops.

EPISODES helps solve these problems by covering both scientific and organizational news. Feature articles contributed by leading geoscientists from all parts of the world - review developments at the frontiers of the earth sciences.

EVERY issue includes reports on new developments in international earth science. Other standard features (e.g. book reviews, training courses, coming events) emphasize the resource aspect of the newsmagazine.

IF you are interested in what is going on globally in the geosciences, you should be reading Episodes on a regular basis.

\section{Your Window to the World}

Global Standards in Stratigraphy

Forecasting Volcanic Eruptions

The Kola Super-Deep Drill Hole

Chinese Loess \& Paleoclimates

Precambrian Paleosols

The Origin of Tethys

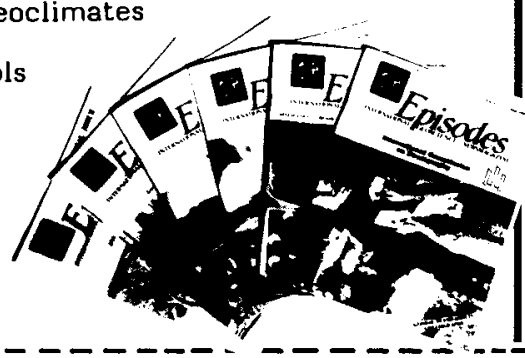

Please enter my subscription to Episodes

\$20-US for a 1 year subscription

(1988 subscription rate)

I Name:

1 Address

I City: Province: 1

Country: Postal Code:

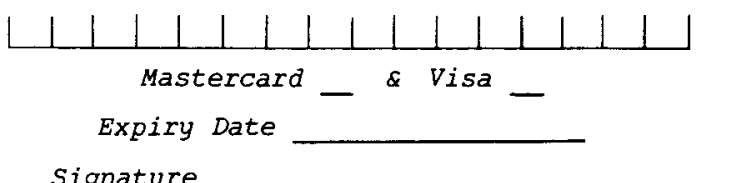

Note: Cheques or money orders must be drawn on a North American bank and made payable to Episodes, Room 177, 601 Booth St., Ottawa, Ontario, CANADA KIA OE8. 